\title{
Reactive Sulfur Species: Hydrolysis of Hypothiocyanite to Give Thiocarbamate-S-oxide
}

\author{
Péter Nagy, Xiaoguang Wang, Kelemu Lemma, and Michael T. Ashby* \\ Department of Chemistry and Biochemistry, University of Oklahoma, \\ 620 Parrington Oval, Norman, OK 73019 \\ Submitted September 12, 2007 \\ Revision Submitted November 14, 2007

\section{SUPPORTING INFORMATION}

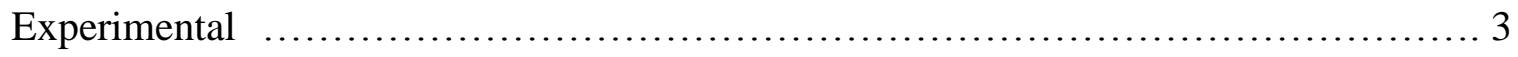

Table S1. Absorbance of thiocarbamate-S-oxide $(233 \mu \mathrm{M})$ vs. $\mathrm{pH}$ at $250 \mathrm{~nm} \ldots \ldots . . .8$

Figure S1 Time resolved UV spectra of the hydrolysis of $\mathrm{OSCN}^{-}$to give $\mathrm{H}_{2} \mathrm{NC}(=\mathrm{O}) \mathrm{SO}^{-}$

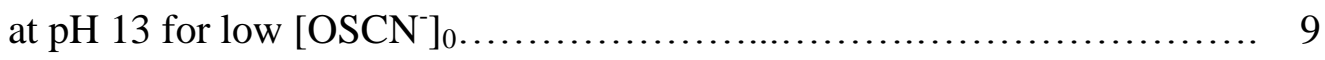

Figure S2. Time resolved UV spectra of the hydrolysis of $\mathrm{OSCN}^{-}$to give $\mathrm{H}_{2} \mathrm{NC}(=\mathrm{O}) \mathrm{SO}^{-}$

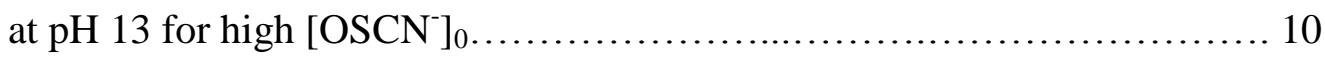

Figure S3 Time resolved ${ }^{13} \mathrm{C}$ NMR spectra of the $\mathrm{OSCN}^{-} \rightarrow 190$ reaction.....................11

Figure S4 Time resolved ${ }^{15} \mathrm{~N}$ NMR spectra of the $\mathrm{OSCN}^{-} \rightarrow 190$ reaction.....................12

Figure S5 Plot of $k_{\mathrm{obs}}$ vs $\left[\mathrm{OH}^{-}\right]_{0}$ for the hydrolysis of $\mathrm{OSCN}^{-}$, in the presence of $0.50 \mathrm{M}$

$\mathrm{SCN}^{-}$

Figure S6. Plot of absorbance of $25 \mu \mathrm{M}$ Tropaeolin $\mathrm{O}$ at $500 \mathrm{~nm}$ vs. [ $\left.\mathrm{OH}^{-}\right]$

Figure S7. UV-vis spectra of the formation of thiocarbamate-S-oxide from the reaction of thiocarbamate $(80 \mu \mathrm{M})$ and $\mathrm{OCl}^{-}(30 \mu \mathrm{M})$ in $0.10 \mathrm{M} \mathrm{NaOH}$ 15

Figure S8. Absorbance of carbamothioperoxoic acid $(250 \mathrm{~nm})$ vs $\left[\mathrm{H}^{+}\right] \ldots \ldots \ldots \ldots \ldots$

Figure S9. Kinetic trace for the reaction between cysteine $(50 \mathrm{mM})$ and ${ }^{-} \mathrm{OSC}(=\mathrm{O}) \mathrm{NH}_{2}$ $(0.61 \mathrm{mM}) /^{-} \mathrm{SC}(=\mathrm{O}) \mathrm{NH}_{2}(1.25 \mathrm{mM})$ in $0.10 \mathrm{M} \mathrm{NaOH}$. 17 
Figure S10. Time resolved spectra of the reaction of ${ }^{-} \mathrm{OSC}(=\mathrm{O}) \mathrm{NH}_{2}$ (generated by the hydrolysis of $\mathrm{OSCN}^{-}$) and $\mathrm{CySH}$ at $\mathrm{pH}=13$. 18

Figure S11. ${ }^{1} \mathrm{H}-\mathrm{NMR}$ spectrum of the reaction mixture of $20 \mathrm{mM}$ cysteine and $2.5 \mathrm{mM}$ thiocarbamate-S-oxide/5.0 mM thiocarbamate (TCM) at $\mathrm{pH} 13.0$ (after $50 \mathrm{~min}$

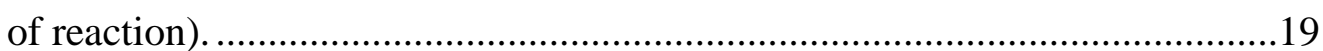

Figure S12. ${ }^{1} \mathrm{H}-\mathrm{NMR}$ spectrum of the reaction mixture of $20 \mathrm{mM}$ cysteine and $2.5 \mathrm{mM}$ thiocarbamate-S-oxide/5.0 mM thiocarbamate (TCM) at pH 13.0 (after 24 hours of reaction) 


\section{EXPERIMENTAL}

Reagents. All chemicals were A.C.S. certified grade or better. Water was doublydistilled in glass. Solutions of $\mathrm{NaOH}$, mostly free of $\mathrm{CO}_{2}$ contamination, were quantified by titration with potassium hydrogen phthalate or standardized $\mathrm{HCl}$ or $\mathrm{HClO}_{4}$ solutions using phenolphthalein as an indicator. $\mathrm{HCl}$ and $\mathrm{HClO}_{4}$ were standardized against bicarbonate. The buffer solutions were prepared from the solids $\mathrm{K}_{3} \mathrm{PO}_{4}, \mathrm{NaH}_{2} \mathrm{PO}_{4} \cdot \mathrm{H}_{2} \mathrm{O}$, $\mathrm{Na}_{2} \mathrm{HPO}_{4}$ and $\mathrm{Na}_{3} \mathrm{PO}_{4} \cdot 12 \mathrm{H}_{2} \mathrm{O}$, the ionic strength was adjusted with $\mathrm{NaClO}_{4}$, and the $\mathrm{pH} / \mathrm{pD}$ was adjusted with $\mathrm{NaOH}, \mathrm{NaOD}, \mathrm{HClO}_{4}$ or DCl. L-Cystine, L-cysteine, L-cysteic acid monohydrate, L-cysteinesulfinic acid monohydrate, peracetic acid, deuterium chloride (35 wt \% solution in $\mathrm{D}_{2} \mathrm{O}$ ), $\mathrm{NaOD}$ (40 wt \% solution in $\mathrm{D}_{2} \mathrm{O}$ ), $\mathrm{NaClO}_{4}$, and $\mathrm{K}_{3} \mathrm{PO}_{4}$ were used as received from Sigma-Aldrich. $\mathrm{NaH}_{2} \mathrm{PO}_{4} \cdot \mathrm{H}_{2} \mathrm{O}, \mathrm{Na}_{2} \mathrm{HPO}_{4}$ and $\mathrm{Na}_{3} \mathrm{PO}_{4} \cdot 12 \mathrm{H}_{2} \mathrm{O}$ was used as received from Mallinckrodt. The monosodium salt of 4-[(2,4dihydroxyphenyl)azo]benzenesulfonic acid (Tropaeolin O) was received from Allied Chemical and Dye Corporation (N.Y. USA). Deuterium oxide (99.9\%) was obtained from Cambridge Isotope Laboratories. Stock solutions of $\mathrm{NaOCl}$ were prepared by sparging $\mathrm{Cl}_{2}$ into a $0.3 \mathrm{M}$ solution of $\mathrm{NaOH}$. The sparging was stopped when the [ $\left.\mathrm{OCl}^{-}\right]$ achieved ca. $100 \mathrm{mM}$, as determined spectrophotometrically $\left(\varepsilon\left(\mathrm{OCl}^{-}\right)_{292 \mathrm{~nm}}=350\right.$ $\mathrm{M}^{-1} \mathrm{~cm}^{-1}$ ). Solutions of $\mathrm{NaOBr}$ were prepared by adding $\mathrm{Br}_{2}$ to ice cold solutions of $\mathrm{NaOH} .{ }^{1}$ Solutions of $\mathrm{OBr}^{-}$were standardized spectrophotometrically at $329 \mathrm{~nm}\left(\varepsilon_{329}=\right.$ $332 \mathrm{M}^{-1} \mathrm{~cm}^{-1}$ ). The solutions of $\mathrm{OBr}^{-}$were used within two hours of the preparations to minimize errors due to decomposition. The synthesis of cysteine thiosulfinate ester, $\mathrm{CyS}(=\mathrm{O}) \mathrm{SCy}$, and cysteine thiosulfonate ester, $\mathrm{CyS}(=\mathrm{O}){ }_{2} \mathrm{SCy}$, were accomplished using a published procedure. ${ }^{2}$

Synthesis of Ammonium Thiocarbamate. Ammonium thiocarbamate was prepared following a standard procedure. ${ }^{3}$ A stirred solution containing $25 \mathrm{~mL}$ of ethyl acetate and $4.2 \mathrm{~mL}$ of ethyl alcohol was bubbled with anhydrous ammonia gas for 12 minutes at -10 ${ }^{\circ} \mathrm{C}$. This was followed by the addition of carbonyl sulfide at $-5{ }^{\circ} \mathrm{C}$ over a six-minute period. Then the mixture was kept in water-ice bath for an additional thirty minutes. The white solid was obtained by filtration, washed with $12 \mathrm{~mL}$ of diethyl ether and air-dried for 30 minutes at room temperature. ${ }^{13} \mathrm{C}$ NMR $(0.10 \mathrm{M} \mathrm{NaOD}, 300 \mathrm{MHz}) \delta 187.39$. UVvis $(0.1 \mathrm{M} \mathrm{NaOH}), \varepsilon_{224}=11,535 \mathrm{M}^{-1} \mathrm{~cm}^{-1}$.

Methods of Generating Thiocarbamate-S-oxide. Essentially two independent procedures were employed to synthesize thiocarbamate-S-oxide, hydrolysis of $\mathrm{OSCN}^{-}$at $\mathrm{pH} 13$ and oxidation of thiocarbamate with HOCl. All three known procedures of synthesizing $\mathrm{OSCN}^{-}$produced thiocarbamate S-oxide upon hydrolysis at $\mathrm{pH} 13$.

Hydrolysis of OSCNproduced by oxidation of $\mathrm{SCN}^{-}$with $\mathrm{HOCl}$. $\mathrm{OSCN}^{-}$was generated at $\mathrm{pH} 13$ by the reaction of $\mathrm{OX}^{-}(\mathrm{X}=\mathrm{Cl}$ or $\mathrm{Br})$ and $\mathrm{SCN}^{-}$in the presence of a sufficiently high excess of $\mathrm{SCN}^{-}$(typically 200-400 fold excess over $\mathrm{OX}^{-}$) to avoid overoxidation. ${ }^{4,5}$ Turbulent mixing of the reagents was necessary to insure homogeneity of the reaction mixtures in the time-frame of the chemical reaction, and this was achieved by employing a hand mixer comprised of two Hamilton syringes and a T-mixer. Failure to quickly mix solutions of $\mathrm{HOX}$ and $\mathrm{SCN}^{-}$resulted in locally high concentrations of $\mathrm{OX}^{-}$and hence overoxidation. For the NMR experiments, a 10 -fold excess of $\mathrm{SCN}^{-}$was employed, 
which results in $>50 \%$ yield of $\mathrm{OSCN}^{-}$(as determined by UV-vis spectroscopy at $\lambda=$ $376 \mathrm{~nm}$ ). The over-oxidation product(s) were not observed by NMR and they did not appear to affect the lifetime of the ${ }^{13} \mathrm{C}$ and ${ }^{15} \mathrm{~N}$ NMR spectra of 190 or OSCN'.

Hydrolysis of OSCNproduced from $(\mathrm{SCN})_{2}$. $(\mathrm{SCN})_{2}$ was generated by the heterogeneous reaction of $\mathrm{Pb}(\mathrm{SCN})_{2}$ with $\mathrm{Br}_{2}$ in $\mathrm{CCl}_{4} . \mathrm{Pb}(\mathrm{SCN})_{2}$ was synthesized by mixing ice-cold aqueous solutions of $\mathrm{Pb}\left(\mathrm{NO}_{3}\right)_{2}$ and $\mathrm{NaSCN}$. The resulting precipitate was filtered, washed with ice-cold water, and dried. The concentration of $\mathrm{Br}_{2}$ in water-saturated $\mathrm{CCl}_{4}$ was determined spectrophotometrically $\left(\varepsilon_{400 \mathrm{~nm}}=160 \mathrm{M}^{-1} \mathrm{~cm}^{-1}\right)$. Excess $\mathrm{Pb}(\mathrm{SCN})_{2}$ was added to the $\mathrm{CCl}_{4}$ solution of $\mathrm{Br}_{2}$ and the resulting slurry was vortexed until the solution became colorless. The $\mathrm{Pb}$ salts were removed by centrifuging and decanting. The concentration of $(\mathrm{SCN})_{2}$ in $\mathrm{CCl}_{4}$ was determined spectrophotometrically $\left(\varepsilon_{296 \mathrm{~nm}}=140 \mathrm{M}^{-}\right.$ $\left.{ }^{1} \mathrm{~cm}^{-1}\right)$. An aliquot of the $\mathrm{CCl}_{4}$ solution of $(\mathrm{SCN})_{2}$ was added to $0.1 \mathrm{M}$ aqueous $\mathrm{NaOH}$ with vigorous stirring (the volume of the aqueous phase was at least 10 times the volume of the $\mathrm{CCl}_{4}$ phase). The two phase solution was vortexed for one minute, then the emulsion was separated into two phases by centrifugation (the top layer is the aqueous phase).

Hydrolysis of OSCN produced from $\mathrm{LPO}$. $\mathrm{OSCN}^{-}$was generated by the LPO catalyzed oxidation of $\mathrm{SCN}^{-}$with $\mathrm{H}_{2} \mathrm{O}_{2}$ at $\mathrm{pH}$ 7.2. The appropriate amounts of $\mathrm{SCN}^{-}$and $\mathrm{LPO}$ were incubated in a $0.1 \mathrm{M}$ iP buffer at $20{ }^{\circ} \mathrm{C}$. The reaction was initiated by the addition of $\mathrm{H}_{2} \mathrm{O}_{2}$. 2.5 minutes after the addition of the $\mathrm{H}_{2} \mathrm{O}_{2}$ aliquot a $\mathrm{pH}$ jump to $\mathrm{pH} 13$ was applied by mixing the reaction mixture (in a 1:1 ratio using a hand mixer comprised of two Hamilton syringes and a T-mixer) with $0.317 \mathrm{M} \mathrm{NaOH}$ solution.

Oxidation of thiocarbamate with $\mathrm{HOCl}$. Thiocarbamate-S-oxide was generated from the oxidation of thiocarbamate by $\mathrm{HOCl}$ in $0.10 \mathrm{M} \mathrm{NaOH}$. The yield of thiocarbamate-Soxide was about $50 \%$ if $\mathrm{HOCl}$ was mixed with 2 molar equivalent of thiocarbamate. To avoid overoxidation and obtain $100 \%$ yield of thiocarbamate-S-oxide, at least 100-fold excess of thiocarbamate is needed (and the solution was vortexed during mixing). Figure S7 shows that the UV-vis spectra of thiocarbamate-S-oxide that was generated from the oxidation of thiocarbamate $(80 \mu \mathrm{M})$ by $\mathrm{HOCl}(30 \mu \mathrm{M})$ in $0.10 \mathrm{M} \mathrm{NaOH}$. Its UV-vis spectra have characteristic absorbance at $250 \mathrm{~nm}$, consistent with that of thiocarbamate$\mathrm{S}$-oxide that was generated from the hydrolysis of $\mathrm{OSCN}^{-}$, as shown in Figure $\mathrm{S} 1$.

Decomposition of Thiocarbamate-S-oxide at Neutral pH. LPO $\left(\begin{array}{lll}0.80 & \mu \mathrm{M}\end{array}\right)$ was employed to catalyze the oxidation of $\mathrm{SCN}^{-}(8.0 \mathrm{mM})$ by $8.0 \mathrm{mM} \mathrm{H}_{2} \mathrm{O}_{2}$ at $\mathrm{pH} 7.0$, with a $50 \%$ yield. Thiocarbamate-S-oxide $(0.10 \mathrm{mM})$ was produced after 150 -minute of hydrolysis of $\operatorname{OSCN}^{-}(0.20 \mathrm{mM})$ at $\mathrm{pH} 13$, then the solution was mixed 1:1 with $200 \mathrm{mM}$ phosphate buffer $\left(\mathrm{I}=1.0 \mathrm{M}, \mathrm{NaClO}_{4}\right)$ to give $\mathrm{pH}$ 6.64. The kinetics of decomposition of thiocarbamate-S-oxide was measured with a HP 8452 diode-array spectrometer.

pH/pD Measurements. The $\left[\mathrm{OH}^{-}\right]$for the unbuffered solutions were determined by acidbase titration against standardized $\mathrm{HCl}$ or standardized $\mathrm{HClO}_{4}$ solutions. The $\left[\mathrm{H}^{+}\right]$of the buffered solutions were determined with an Orion Ion Analyzer EA920 using an $\mathrm{Ag} / \mathrm{AgCl}$ combination $\mathrm{pH}$ electrode. The ionic strength was kept constant at $1.0 \mathrm{M}$ for 
most solutions $\left(\mathrm{NaClO}_{4}+\mathrm{NaOH} / \mathrm{iP}\right)$. To obtain the $\left[\mathrm{H}^{+}\right]$or $\left[\mathrm{OH}^{-}\right]$of the buffered solutions from the measured $\mathrm{pH}$ values, all $\mathrm{pH}$ measurements were corrected for the "Irving factor" and the ionic product of water $\left(\mathrm{pK}_{\mathrm{w}}\right)$ that were measured by titration of a 1.0 $\mathrm{M} \mathrm{NaClO}_{4}$ solution by a standardized $0.1 \mathrm{M} \mathrm{NaOH}$ (in $1.0 \mathrm{M} \mathrm{NaClO}_{4}$ ) solution. $\mathrm{pD}$ measurements in $\mathrm{D}_{2} \mathrm{O}$ were made using the same $\mathrm{pH}$ electrode by adding 0.4 units to the measurement.

NMR Studies. ${ }^{1} H$ NMR Measurements. ${ }^{1} \mathrm{H}$ NMR spectra were recorded with a Varian XL-300 spectrometer at $20( \pm 0.5){ }^{\circ} \mathrm{C}$. Deuterated buffers were prepared from $\mathrm{D}_{2} \mathrm{O}$ solutions of anhydrous $\mathrm{K}_{3} \mathrm{PO}_{4}$ by adding $\mathrm{DCl}$, by dilution of a 40 wt $\%$ NaOD solution with $\mathrm{D}_{2} \mathrm{O}$ or by dilution of a $35 \mathrm{wt} \% \mathrm{DCl}$ solution with $\mathrm{D}_{2} \mathrm{O}$. The chemical shifts (ppm) were referenced to sodium 2,2-dimethyl-2-silapentane-5-sulfonate (DSS, $\delta=0.015 \mathrm{ppm}$ ). ${ }^{13} \mathrm{C} N M R$ Measurements. The ${ }^{13} \mathrm{C}$ NMR measurements were made with a Varian Inova $400 \mathrm{MHz}$ NMR spectrometer at $100.57 \mathrm{MHz}$ using a Varian 4-nuclei switchable $5 \mathrm{~mm}$ probe while employing $\mathrm{D}_{2} \mathrm{O}$ as a frequency lock. Chemical shifts were referenced to internal dioxane $(\delta=66.6 \mathrm{ppm}) .{ }^{15} N$ NMR Measurements. The ${ }^{15} \mathrm{~N}$ NMR measurements were made with a Varian Inova $600 \mathrm{MHz}$ NMR spectrometer at $60.79 \mathrm{MHz}$ using a Varian broadband $5 \mathrm{~mm}$ probe while employing $\mathrm{D}_{2} \mathrm{O}$ as a frequency lock. Chemical shifts were referenced to external $\mathrm{NO}_{3}{ }^{-}(0.0 \mathrm{ppm})$.

Ion Chromatography. Ion chromatography was performed on a Dionex ICS-3000 with $100 \mathrm{mM}$ of $\mathrm{NaOH}$ as eluents. For the anions that were measured using an integrated amperometry detector, the experimental conditions were: eluents gradient, $5-10 \mathrm{~min}, 5$ $\mathrm{mM} ; 10-25 \mathrm{~min}, 60 \mathrm{mM}$. Column: Ionpac AS16. Sample holder tray temperature: 10 ${ }^{\circ} \mathrm{C}$; Detection compartment temperature: $30{ }^{\circ} \mathrm{C}$. Volume of the injection loop: $10 \mu \mathrm{L}$. For the anions that were detected by conductivity mode, the experimental conditions were set as: eluents gradient, 5 - $16 \mathrm{~min}, 12 \mathrm{mM} \mathrm{NaOH}$; $10-25 \mathrm{~min}, 60 \mathrm{mM} \mathrm{NaOH}$. Column: Ionpac $® A S 18$. Suppressor type: ASRS_4mm. Sample holder tray temperature: $10{ }^{\circ} \mathrm{C}$; Column temperature: $30{ }^{\circ} \mathrm{C}$. Detection compartment temperature: $30{ }^{\circ} \mathrm{C}$. Cell-heat temperature: $35{ }^{\circ} \mathrm{C}$. Volume of the injection loop: $10 \mu \mathrm{L}$. The anions $\mathrm{OSCN}^{-}$, $\mathrm{H}_{2} \mathrm{NC}(=\mathrm{O}) \mathrm{SO}^{-}, \mathrm{CN}^{-}, \mathrm{SCN}^{-}$and $\mathrm{HS}^{-}$were measured using an integrated amperometry detector. The ions $\mathrm{SO}_{3}{ }^{2-}, \mathrm{SO}_{4}{ }^{2-}, \mathrm{S}_{2} \mathrm{O}_{3}{ }^{2-}, \mathrm{OCN}^{-}, \mathrm{Cl}^{-}, \mathrm{Br}^{-}$and other halogen derivatives were measured by a conductivity detector. Six standard solutions with different concentrations (in the desired concentration range) were used to develop the calibration curves. Each solution was injected 6 times to ensure reproducibility. All data points (6x6) were used in the development of the standard curves.

UV/vis Spectroscopy. Electronic spectra were measured using a HP 8452A diode array spectrophotometer using quartz cells with calibrated $1 \mathrm{~mm}, 2 \mathrm{~mm}$ and $1 \mathrm{~cm}$ path lengths at $20{ }^{\circ} \mathrm{C}$, or the monochromator of the HI-TECH SF-61 DX2 stopped-flow instrument with a Xe arc lamp at $18{ }^{\circ} \mathrm{C}$.

Kinetic Hydrolysis of OSCN${ }^{-}$. The kinetics of hydrolysis of $\mathrm{OSCN}^{-}$was studied in the range of 0.025 to $0.55 \mathrm{M} \mathrm{OH}^{-}$. The hydrolysis of $\mathrm{OSCN}^{-}$follows pseudo first-order kinetic dependence on $\mathrm{OSCN}^{-}$, and the first-order rate constant is proportional to the 
concentration of hydroxide, as shown in Figure S5, with a rate constant of $(4.24 \pm 0.05) \times$ $10^{-3} \mathrm{M}^{-1} \mathrm{~s}^{-1}$.

Acid Dissociation Constant of Thiocarbamate-S-oxide. Thiocarbamate-S-oxide generated from the extraction of $(\mathrm{SCN})_{2}$ in $0.10 \mathrm{M} \mathrm{NaOH}$. The UV-vis spectra of carbamothioperoxoic acid at various $\mathrm{pH}$ were obtained by mixing thiocarbamate-S-oxide $(0.46 \mathrm{mM})$ with the corresponding buffer solutions with the ratio of $1: 1$ (i.e., [thiocarbamate-S-oxide] $=0.23 \mathrm{mM}$ after mixing $)$. The absorbance $(250 \mathrm{~nm})$ are shown in Table 1. Plot of absorbance at $250 \mathrm{~nm}$ versus $\left[\mathrm{H}^{+}\right]$is shown in Figure S8. The parameters $\left(\varepsilon_{250}(\mathrm{HA}), \varepsilon_{250}(\mathrm{~A})\right.$ and $\left.K_{\mathrm{a}}\right)$ were obtained by fitting the experimental results with the following equation:

$$
A=\frac{\varepsilon_{H A}\left[H^{+}\right]+\varepsilon_{A} K_{a}}{\left[H^{+}\right]+K_{a}}[C]_{t o t}
$$

Where $\varepsilon_{250}(\mathrm{HA})=(214 \pm 36) \mathrm{M}^{-1} \mathrm{~cm}^{-1} ; \varepsilon_{250}(\mathrm{~A})=3381 \mathrm{M}^{-1} \mathrm{~cm}^{-1} ; K_{\mathrm{a}}=(2.10 \pm 0.13) \times 10^{-7}$ M. Based on the above experimental and fitting results, the $p K_{\mathrm{a}}$ of carbamothioperoxoic acid $(\mathrm{I}=1.0 \mathrm{M})$ was calculated to be $6.68(3)$.

Reaction of Thiocarbamate S-oxide with Cysteine. Thiocarbamate-S-oxide $(0.62 \mathrm{mM})$ was generated from the oxidation of thiocarbamate $(2.5 \mathrm{mM})$ by hypochlorite $(1.25 \mathrm{mM})$ in $0.10 \mathrm{mM} \mathrm{NaOH}$ (yield of thiocarbamate-S-oxide: $\approx 50 \%$ ). Part of the kinetic trace in the oxidation of cysteine $(25.0 \mathrm{mM})$ by thiocarbamate-S-oxide $(0.31 \mathrm{mM})$ in $0.10 \mathrm{M}$ $\mathrm{NaOH}$ is shown in Figure S9. It demonstrates that an intermediate product was formed with a rate constant of $(1.40 \pm 0.09) \times 10^{-3} \mathrm{~s}^{-1}$, which then reacts slowly with cysteine to form cystine and thiocarbamate (Refer to the ${ }^{1} \mathrm{H}-\mathrm{NMR}$ spectra). The identification of the product of the reaction of thiocarbamate-S-oxide with excess cysteine in $0.10 \mathrm{M} \mathrm{NaOH}$ were made by ${ }^{1} \mathrm{H}-\mathrm{NMR}$ spectroscopy. Figure S11 shows the ${ }^{1} \mathrm{H}-\mathrm{NMR}$ spectrum for the reaction between cysteine $(20 \mathrm{mM})$ and thiocarbamate-S-oxide $(2.5 \mathrm{mM})$ / thiocarbamate $(5.0 \mathrm{mM})$ in $0.10 \mathrm{M} \mathrm{NaOH}$ after 50 minutes of reaction. The appearance of two new peaks $(3.60(\mathrm{dd}, \mathrm{J}=9.3,3.9 ; 2 \mathrm{H}) ; 2.60$, $(\mathrm{dd}, \mathrm{J}=13.2,9.3 ; 2 \mathrm{H})$; the other peak overlap with cysteine) confirms the formation of an intermediate product which is assigned as the thiocarbamate/cysteine mixed didulfide. The intermediate then slowly reacts with the excess cysteine to form cystine and thiocarbamate, as shown in Figure S12. Similar results were obtained when thiocarbamate-S-oxide was generated by the hydrolysis of $\mathrm{OSCN}^{-}$(Figure S10).

Quantification of $\left[\mathrm{OH}^{-}\right]$in the Hydrolysis of $\mathrm{OSCN}^{-}$. The concentration of $\mathrm{OH}^{-}$during the hydrolysis of $\mathrm{OSCN}^{-}$was determined by using Tropaeolin $\mathrm{O}$ as indicator. The UV-vis absorbance of Tropaeolin $\mathrm{O}$ at $500 \mathrm{~nm}$ is proportional to its concentration in a very narrow $\mathrm{pH}$ range (Figure S6 illustrates the calibration curve of Tropaeolin $\mathrm{O}$ for $0.50 \leq$ $\left[\mathrm{OH}^{-}\right] \leq 8.0 \mathrm{mM}$ ). Since Tropaeolin $\mathrm{O}$ is photosensitive, the change in $\left[\mathrm{OH}^{-}\right]$during the hydrolysis of $\mathrm{OSCN}^{-}$could not be obtained in real time. Instead, $\mathrm{OSCN}^{-}(2.5 \mathrm{mM})$ in 5.0 $\mathrm{mM} \mathrm{NaOH}$ was prepared from the oxidation of $\mathrm{SCN}^{-}(1.0 \mathrm{M})$ by $\mathrm{OCl}^{-}(5.0 \mathrm{mM})$ in 0.10 $\mathrm{M} \mathrm{NaOH}$. A pH-jump to $5.0 \mathrm{mM} \mathrm{NaOH}$ was achieved by dilution of the $\mathrm{OSCN}^{-}$solution. The $\left[\mathrm{OH}^{-}\right]$was obtained by $\mathrm{UV}$-vis spectroscopy every hour during the hydrolysis of $\mathrm{OSCN}^{-}$by adding Tropaeolin $\mathrm{O}(25 \mu \mathrm{M})$ to an aliquot of the reaction mixture. The results 
indicate that the $\left[\mathrm{OH}^{-}\right]$did not change during the hydrolysis of $\mathrm{OSCN}^{-}$in $5.0 \mathrm{mM} \mathrm{NaOH}$ (over a period of $10 \mathrm{~h}$ ).

Qualitative Analysis of $\mathbf{S}_{8}$. Qualitative analysis of the $\mathrm{S}_{8}$ the precipitate that forms upon the hydrolysis of thiocarbamate-S-oxide was carried out by mass spectrometry (VG ZAB $\mathrm{SE}$ two sector mass spectrometer, using EI/CI ionization source) by direct infusion. The molecular mass, fragmentation and isotope patterns allowed us to identify the yellow precipitate as cyclooctasulfur.

Quantitative Analysis of $\mathbf{S}_{\mathbf{8}}$. $\mathrm{OSCN}^{-}$was generated by the reaction of $\mathrm{SCN}^{-}(515 \mathrm{mM})$ and $\mathrm{OCl}^{-}(2.48 \mathrm{mM})$ at $\mathrm{pH}=13$ and $\mathrm{T}=20{ }^{\circ} \mathrm{C}$ using turbulent mixing conditions. Based on preliminary experiments under these conditions, no overoxidation could be observed. The reaction mixture was incubated in the dark for 3 hours (the time that is required for the hydrolysis reaction of $\mathrm{OSCN}^{-}$to be completed). The incubation was followed by a $\mathrm{pH}$-jump to 6.98 by a $1: 1$ mixing with a $\mathrm{iP}=0.1 \mathrm{M},[\mathrm{HCl}]=0.1 \mathrm{M}$ buffer. The reaction mixture was incubated for an additional 1 hour after the $\mathrm{pH}$ jump in order for the decomposition of thiocarbamate-S-oxide to be completed. The yellow precipitate was extracted into $\mathrm{CHCl}_{3}$ (the volume of the $\mathrm{CHCl}_{3}$ phase was at least 5 times the volume of the aqueous phase). The two phases were separated and the sulfur concentration of the $\mathrm{CHCl}_{3}$ phase was determined by UV-vis spectroscopy using $\varepsilon_{280}=811 \mathrm{M}^{-1} \mathrm{~cm}^{-1}$ (that was determined in a separate experiment by dissolving different amounts of the authentic sample of $\mathrm{S}_{8}$ in $\mathrm{CHCl}_{3}$ ). Note that the electronic spectrum of the precipitate from the reaction mixture was similar to the electronic spectrum of the authentic sample (in $\left.\mathrm{CHCl}_{3}\right)$. The stoichiometry of the reaction is found to be: $1{ }^{-} \mathrm{OSC}(=\mathrm{O}) \mathrm{NH}_{2} \rightarrow 1 \mathrm{~S}$. The experiment was repeated 5 times and similar results were obtained.

Kinetic Data Analysis. Polychromatic data were analyzed using SPECFIT/32 (Spectrum Software Associates), a multivariate data analysis program. The concentration dependencies of the pseudo-first-order rate constants were obtained by linear leastsquares fits of the data with KaleidaGraph 3.6 (Synergy Software).

1. Troy, R. C.; Margerum, D. W., Inorg. Chem. 1991, 30, 3538-43.

2. Nagy, P.; Ashby, M. T., Chem. Res. Toxicol. 2007, 20, 79-87.

3. Mueller-Litz, W.; Thomzik, D., J. Praktische Chemie (Leipzig) 1977, 319, 677-81.

4. Nagy, P.; Alguindigue, S. S.; Ashby, M. T., Biochemistry 2006, 45, 12610-12616.

5. Ashby, M. T.; Carlson, A. C.; Scott, M. J., J. Am. Chem. Soc. 2004, 126, 1597615977. 
Table S1. Absorbance of thiocarbamate-S-oxide $(233 \mu \mathrm{M}$ and $\mathrm{I}=1.0) \mathrm{vs}$. $\mathrm{pH}$ at $250 \mathrm{~nm}$.

\begin{tabular}{ccccc}
\hline & {$\left[\mathrm{NaClO}_{4}\right], \mathrm{M}$} & [buffer], M & $\mathrm{pH}$ & $\mathrm{Abs}, 250 \mathrm{~nm}$ \\
\hline$\# 1$ & 0.85 & [acetate] $=0.10$ & 4.12 & 0.03638 \\
$\# 2$ & 0.85 & [acetate] $=0.10$ & 4.61 & 0.04726 \\
$\# 3$ & 0.85 & [acetate] $=0.10$ & 5.13 & 0.06943 \\
$\# 4$ & 0.85 & [acetate] $=0.10$ & 5.48 & 0.10239 \\
$\# 5$ & 0.71 & [phosphate] $=0.10$ & 6.09 & 0.23203 \\
$\# 6$ & 0.69 & [phosphate] $=0.10$ & 6.46 & 0.34335 \\
$\# 7$ & 0.68 & [phosphate] $=0.10$ & 6.67 & 0.40273 \\
$\# 8$ & 0.67 & [phosphate] $=0.10$ & 6.90 & 0.50029 \\
$\# 9$ & 0.66 & [phosphate] $=0.10$ & 7.31 & 0.64613 \\
$\# 10$ & 0.85 & [tris] $=0.10$ & 7.90 & 0.74242 \\
$\# 11$ & 0.85 & [tris] $=0.10$ & 8.40 & 0.77168 \\
$\# 12$ & 0.80 & [carbonate] $=0.10$ & 9.52 & 0.79232 \\
$\# 13$ & 0.76 & [carbonate] $=0.10$ & 9.83 & 0.81443 \\
\hline
\end{tabular}




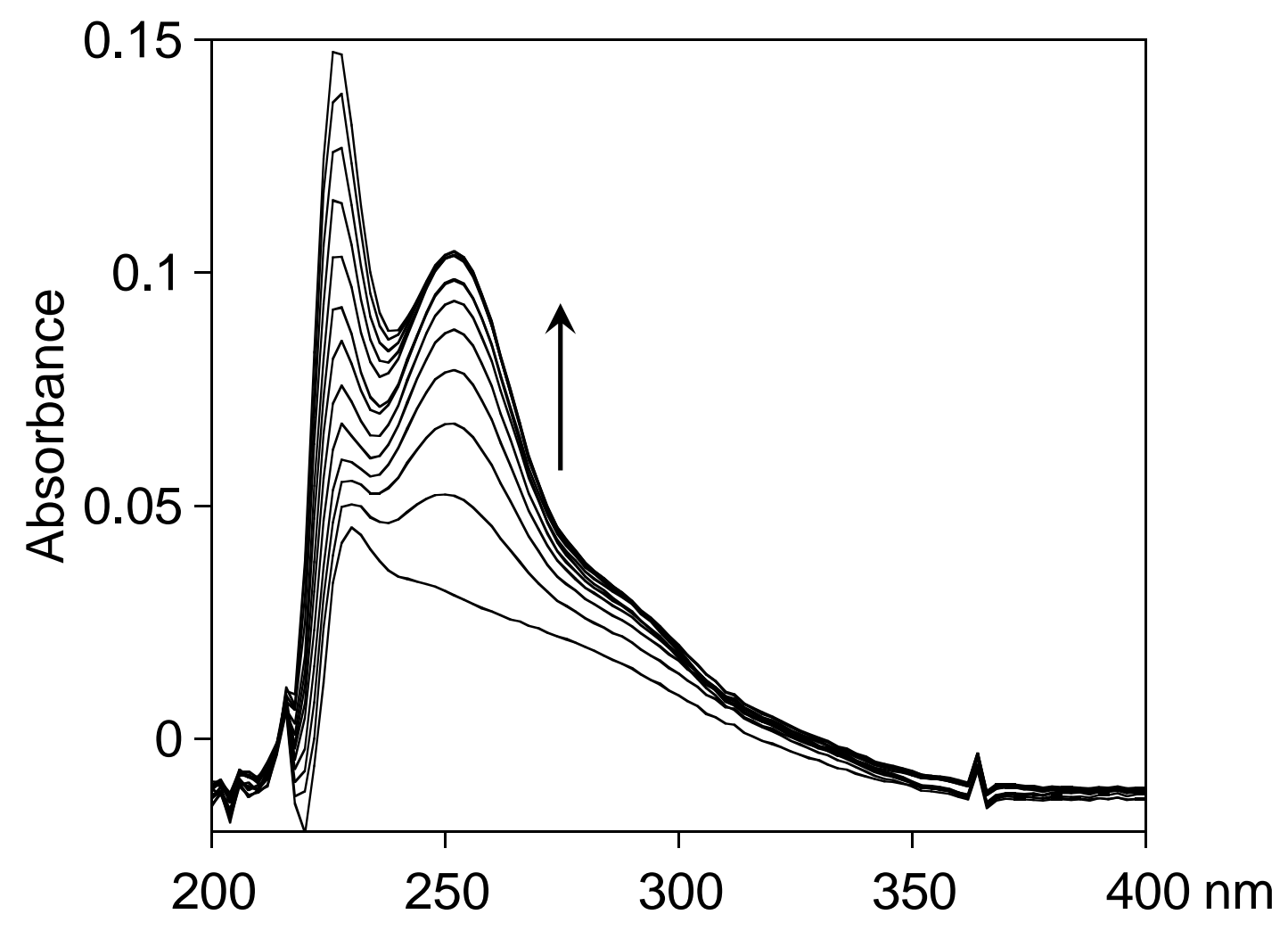

Figure S1. Time resolved UV spectra of the hydrolysis of $\mathrm{OSCN}^{-}$to give $\mathrm{H}_{2} \mathrm{NC}(=\mathrm{O}) \mathrm{SO}^{-}$at $\mathrm{pH} 13$ for low $\left[\mathrm{OSCN}^{-}\right]_{0}$. The spectra are $150 \mathrm{~s}$ apart. $\mathrm{OSCN}^{-}$was generated in the reaction of $49.8 \mu \mathrm{M} \mathrm{OCl}^{-}$and $550 \mu \mathrm{M} \mathrm{SCN}$ at $\mathrm{pH}=13$. The spectrum of the excess $\mathrm{SCN}^{-}$and $\mathrm{NaOH}$ were subtracted from each spectrum. Conditions: $\left[\mathrm{OCl}^{-}\right]_{0}=49.8 \mu \mathrm{M},\left[\mathrm{SCN}^{-}\right]_{0}=550 \mu \mathrm{M}, \mathrm{pH}=13, \mathrm{~T}=20^{\circ} \mathrm{C}$. 


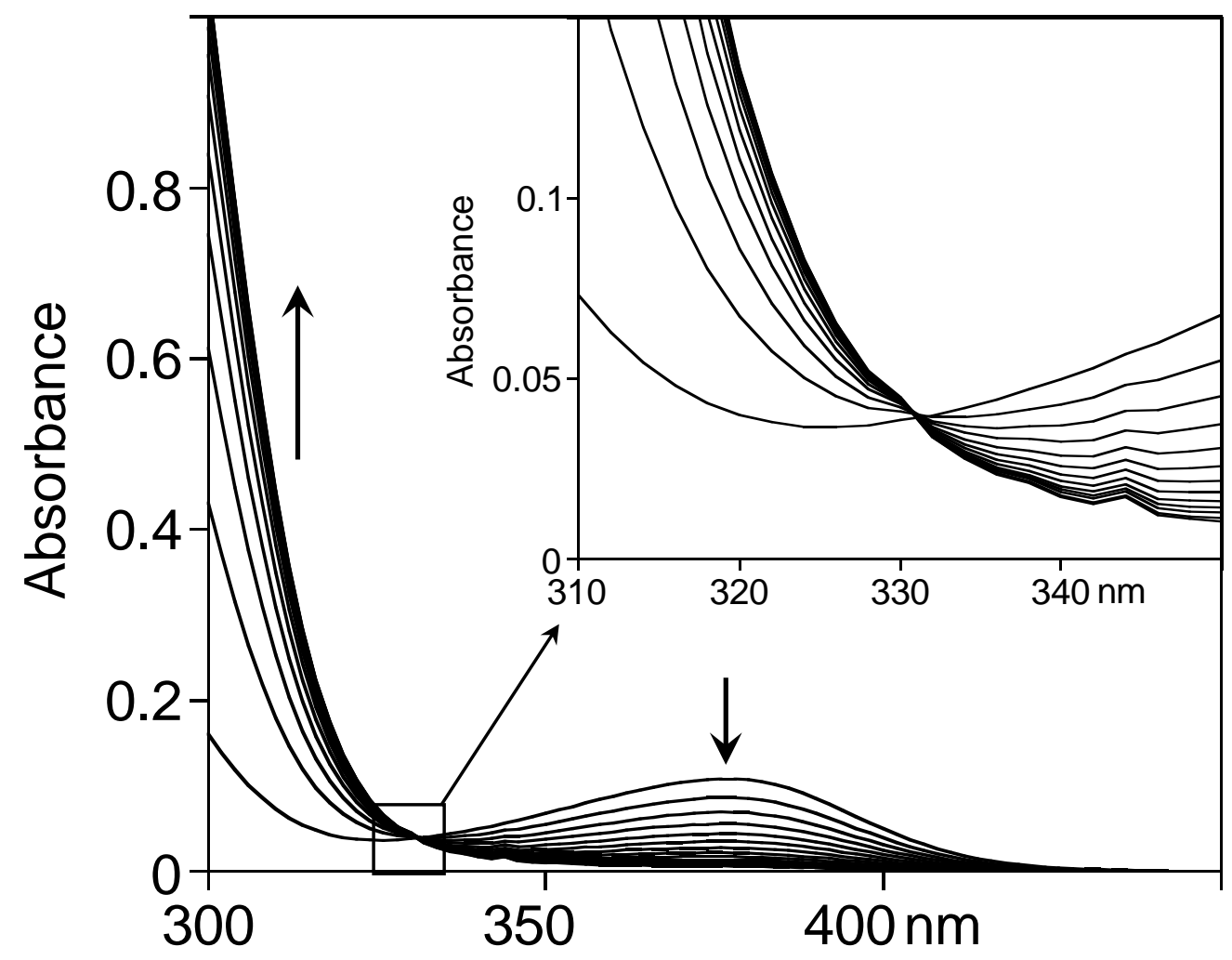

Figure S2. Time resolved UV spectra of the hydrolysis of $\mathrm{OSCN}^{-}$to give $\mathrm{H}_{2} \mathrm{NC}(=\mathrm{O}) \mathrm{SO}^{-}$at $\mathrm{pH} 13$ for high $\left[\mathrm{OSCN}^{-}\right]_{0}$. The spectra are $213 \mathrm{~s}$ apart. $\mathrm{OSCN}^{-}$was generated in the reaction of $10 \mathrm{mM} \mathrm{OCl}^{-}$and $100 \mathrm{mM} \mathrm{SCN}^{-}$at $\mathrm{pH}$ = 13. Conditions: $\left[\mathrm{OCl}^{-}\right]_{0}=10 \mathrm{mM},\left[\mathrm{SCN}^{-}\right]_{0}=100 \mathrm{mM}, \mathrm{pH}=13, \mathrm{~T}=20{ }^{\circ} \mathrm{C}$. Notice the isosbestic point (inset). 


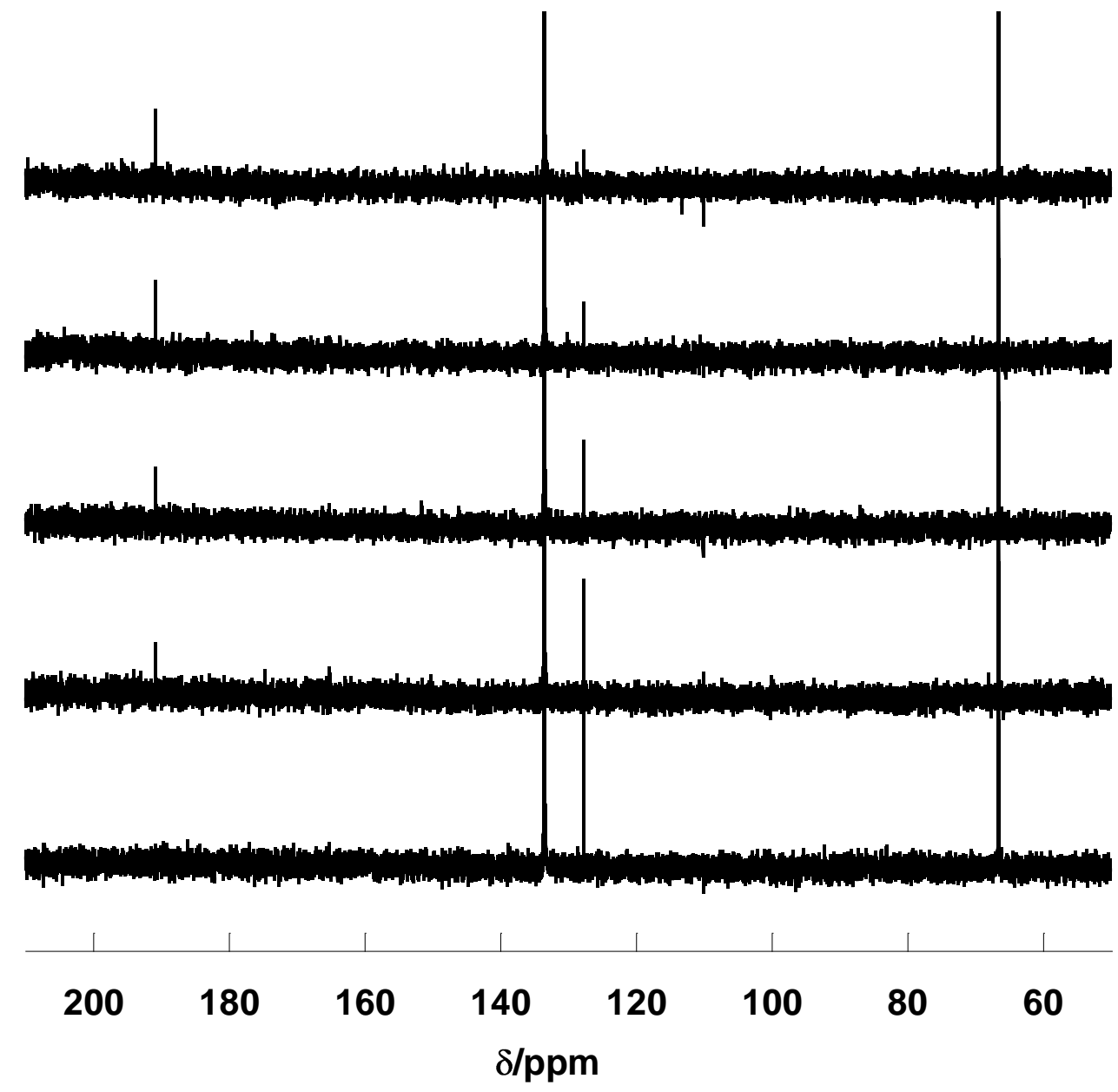

Figure S3. Time resolved ${ }^{13} \mathrm{C}$ NMR spectra (from bottom to top) of the $\mathrm{OSCN}^{-} \rightarrow 190$ reaction. $\mathrm{OSCN}^{-}$was generated by the oxidation of 100 $\mathrm{mM} \mathrm{SCN}{ }^{-}$with $10 \mathrm{mM} \mathrm{OCl}^{-}$in $0.10 \mathrm{~N} \mathrm{NaOH}$. Conditions: $\left[\mathrm{OCl}^{-}\right]_{0}=10$ $\mathrm{mM},\left[\mathrm{S}^{13} \mathrm{CN}^{-}\right]_{0}=100 \mathrm{mM}, \mathrm{pH}=13, \mathrm{~T}=20{ }^{\circ} \mathrm{C}$, dead time (between mixing and starting the data collection): 1 min $21 \mathrm{~s}$, spectra are 26 min and $32 \mathrm{~s}$ apart, $\mathrm{nt}=128, \mathrm{~d} 1=5 \mathrm{~s}$. Peak assignments: $\delta$ (Dioxane internal standard $=$ $66.6 \mathrm{ppm}), \delta\left(\mathrm{OSCN}^{-}\right)=127.8 \mathrm{ppm}, \delta\left(\mathrm{SCN}^{-}\right)=136.5 \mathrm{ppm}$, $\delta\left(\mathrm{OSC}(=\mathrm{O}) \mathrm{NH}_{2}\right)=190.9 \mathrm{ppm}$. 

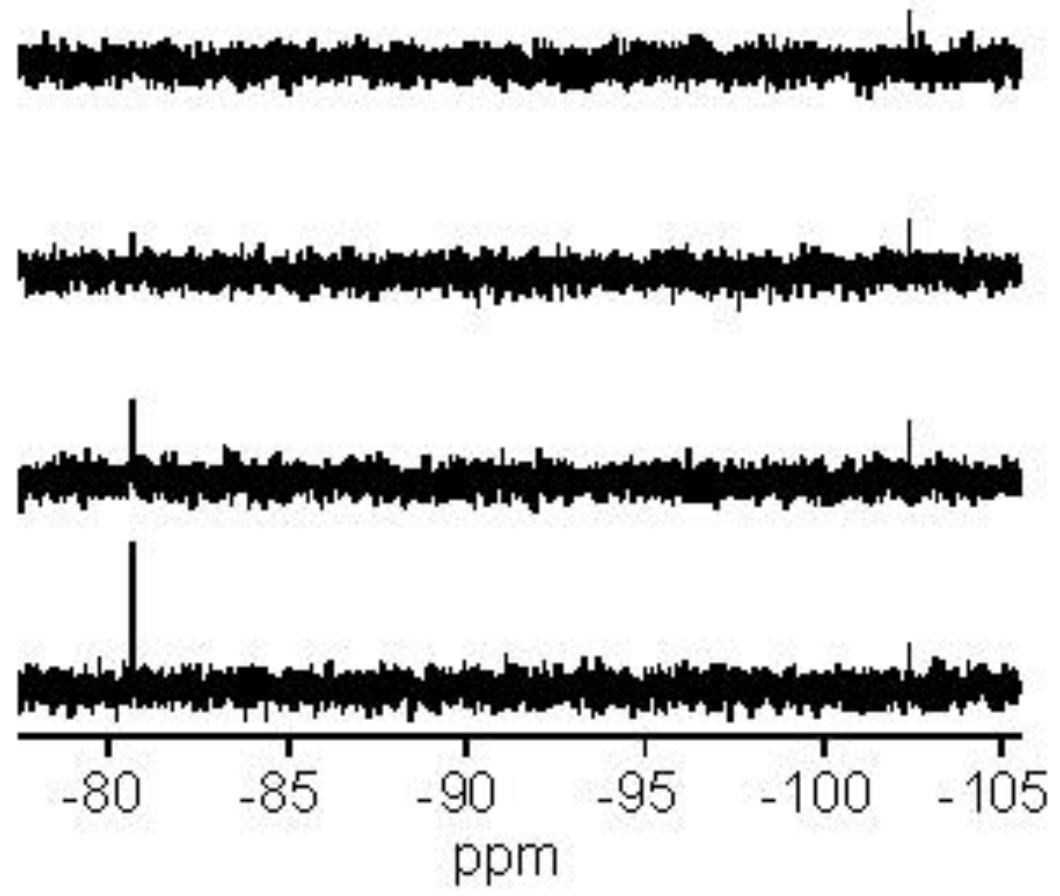

Figure S4. Time resolved ${ }^{15} \mathrm{~N}$ NMR spectra (from bottom to top) of the $\mathrm{OSCN}^{-} \rightarrow 190$ reaction. $\mathrm{OSCN}^{-}$was generated by the reaction of $\mathrm{OCl}^{-}$with $\mathrm{SCN}^{-}$. Conditions: $\left[\mathrm{OCl}^{-}\right]_{0}=20 \mathrm{mM}$, $\left[\mathrm{S}^{15} \mathrm{CN}^{-}\right]_{0}=200 \mathrm{mM}, \mathrm{pH}=13, \mathrm{~T}=20{ }^{0} \mathrm{C}$, dead time (between mixing and starting the data collection) $=53 \mathrm{~s}$, spectra are 35 $\min$ and $15 \mathrm{~s}$ apart, $\mathrm{nt}=64, \mathrm{~d} 1=25 \mathrm{~s}$, at $=8$, sw $=$ from 295.38 to $34.35 \mathrm{ppm}$, fn (zero filling) $=524$ 288. Peak assignments: $\delta\left(\mathrm{OSCN}^{-}\right)=-80.6 \mathrm{ppm}, \delta\left({ }^{-} \mathrm{OSC}(=\mathrm{O}) \mathrm{NH}_{2}\right)=-$ $101.6 \mathrm{ppm}$. 


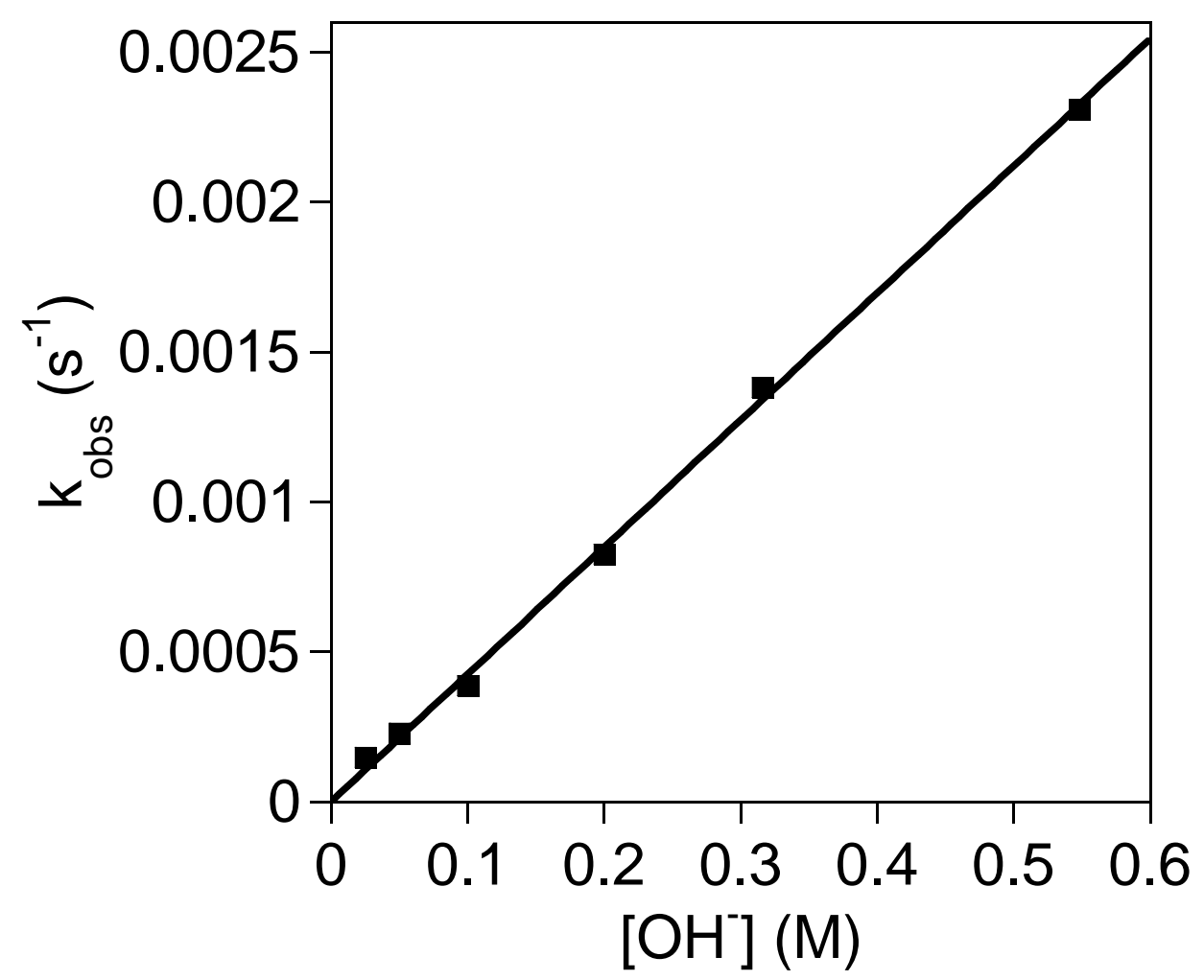

Figure S5. Plot of $k_{\mathrm{obs}}$ vs $\left[\mathrm{OH}^{-}\right]_{0}$ for the hydrolysis of $\mathrm{OSCN}^{-}$, in the presence of $0.50 \mathrm{M} \mathrm{SCN}^{-}$, and at $\mathrm{I}=1.0 \mathrm{M}\left(\mathrm{NaClO}_{4}\right)$. Slope: $(4.24 \pm$ $0.05) \times 10^{-3} \mathrm{M}^{-1} \mathrm{~s}^{-1}$. 


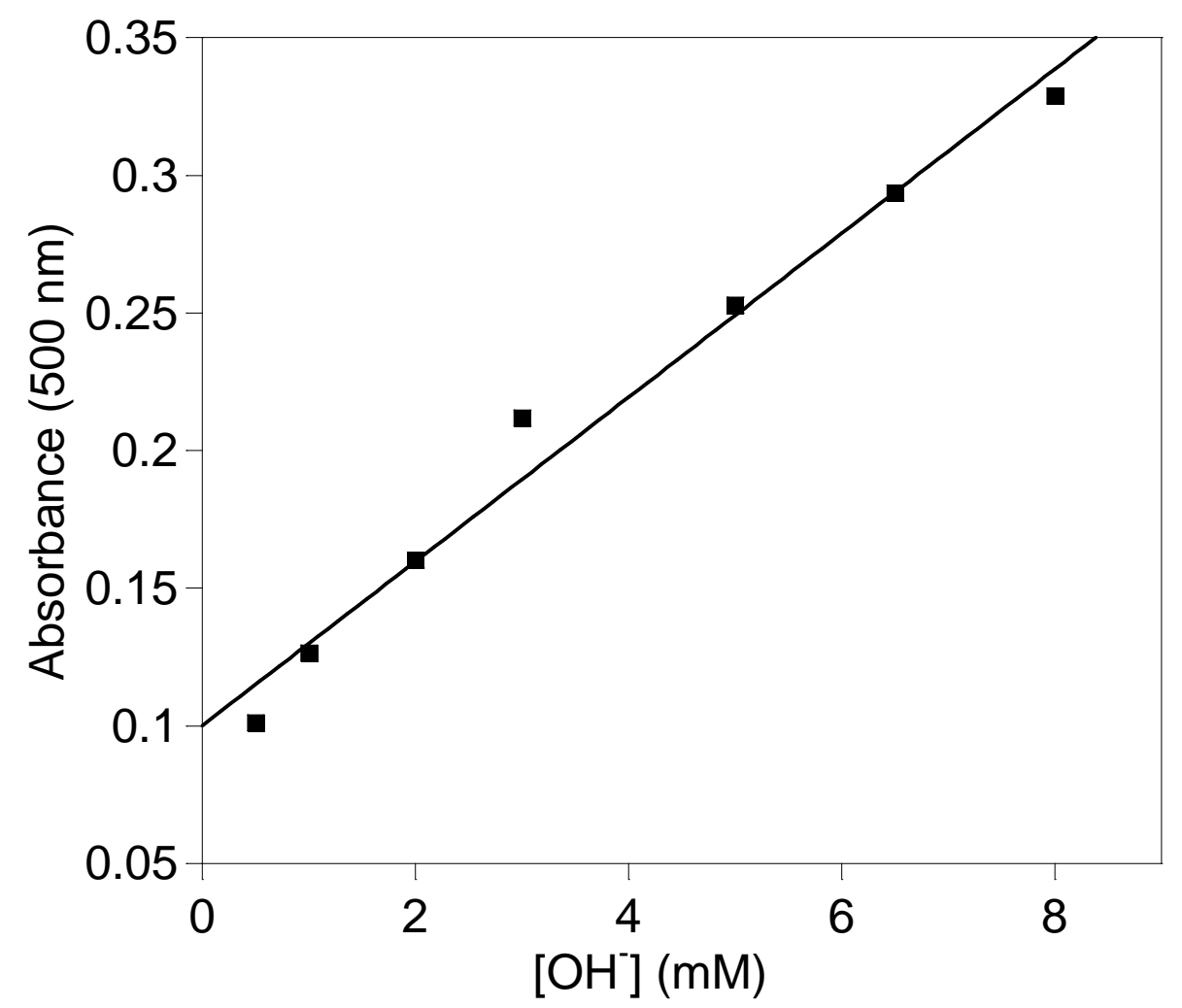

Figure S6. Plot of absorbance of $25 \mu \mathrm{M}$ Tropaeolin $\mathrm{O}$ at $500 \mathrm{~nm}$ vs $\left[\mathrm{OH}^{-}\right]$. 


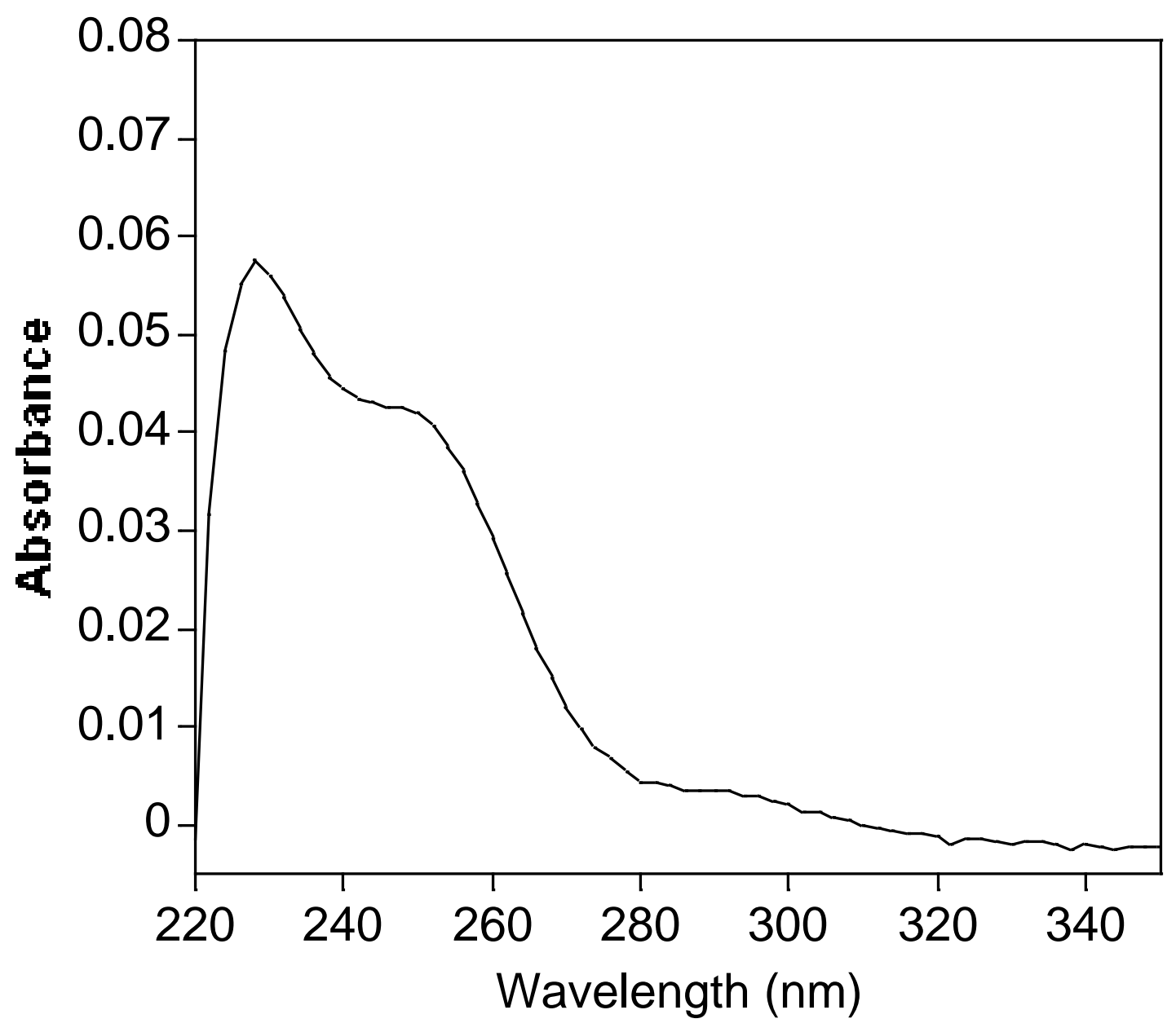

Figure S7. UV-vis spectrum of thiocarbamate-S-oxide from the reaction of thiocarbamate $(80 \mu \mathrm{M})$ and $\mathrm{OCl}^{-}(30 \mu \mathrm{M})$ in $0.10 \mathrm{M} \mathrm{NaOH}$. 


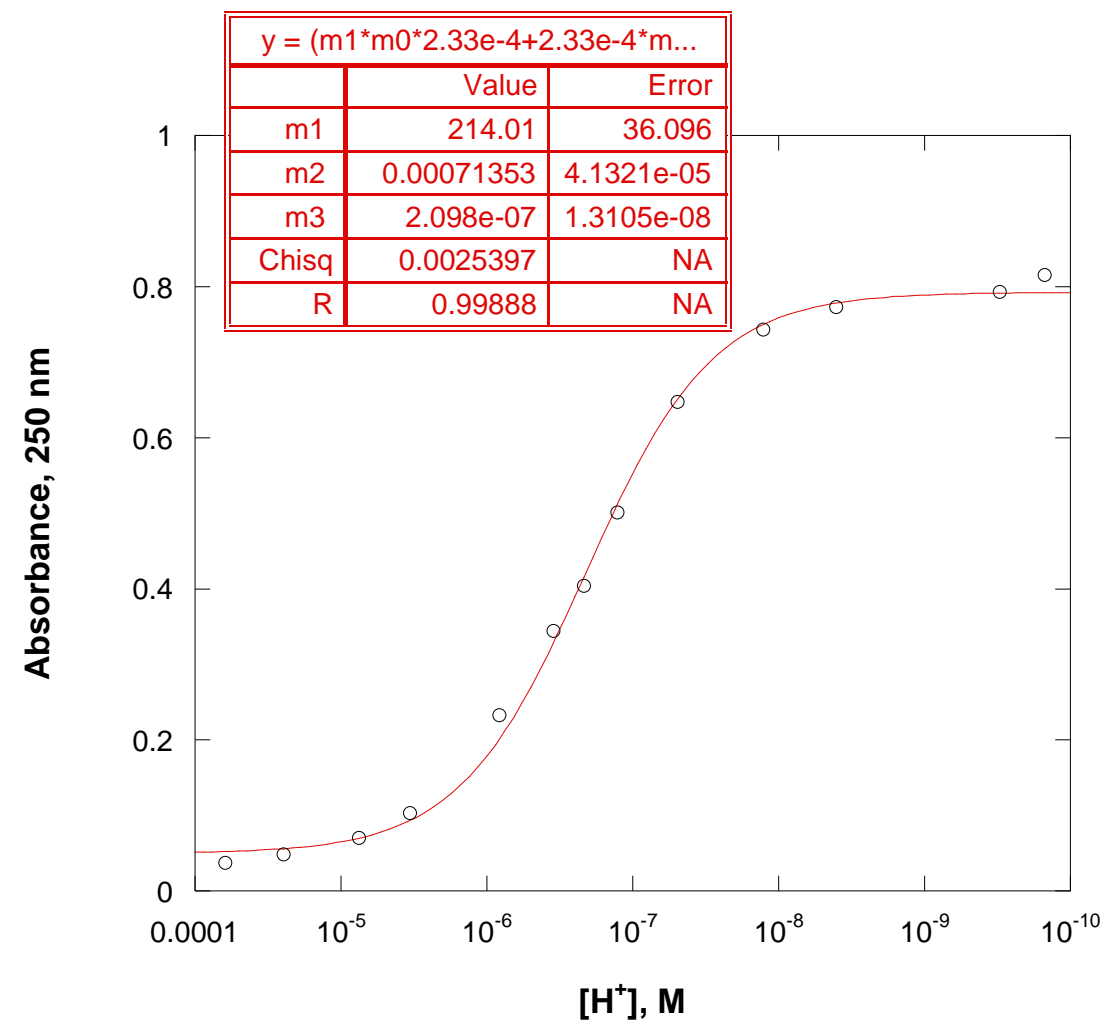

Figure S8. Absorbance of carbamothioperoxoic acid at $250 \mathrm{~nm}$ vs $\left[\mathrm{H}^{+}\right]\left(\mathrm{I}=1.0 \mathrm{M}, \mathrm{NaClO}_{4}\right)$. 


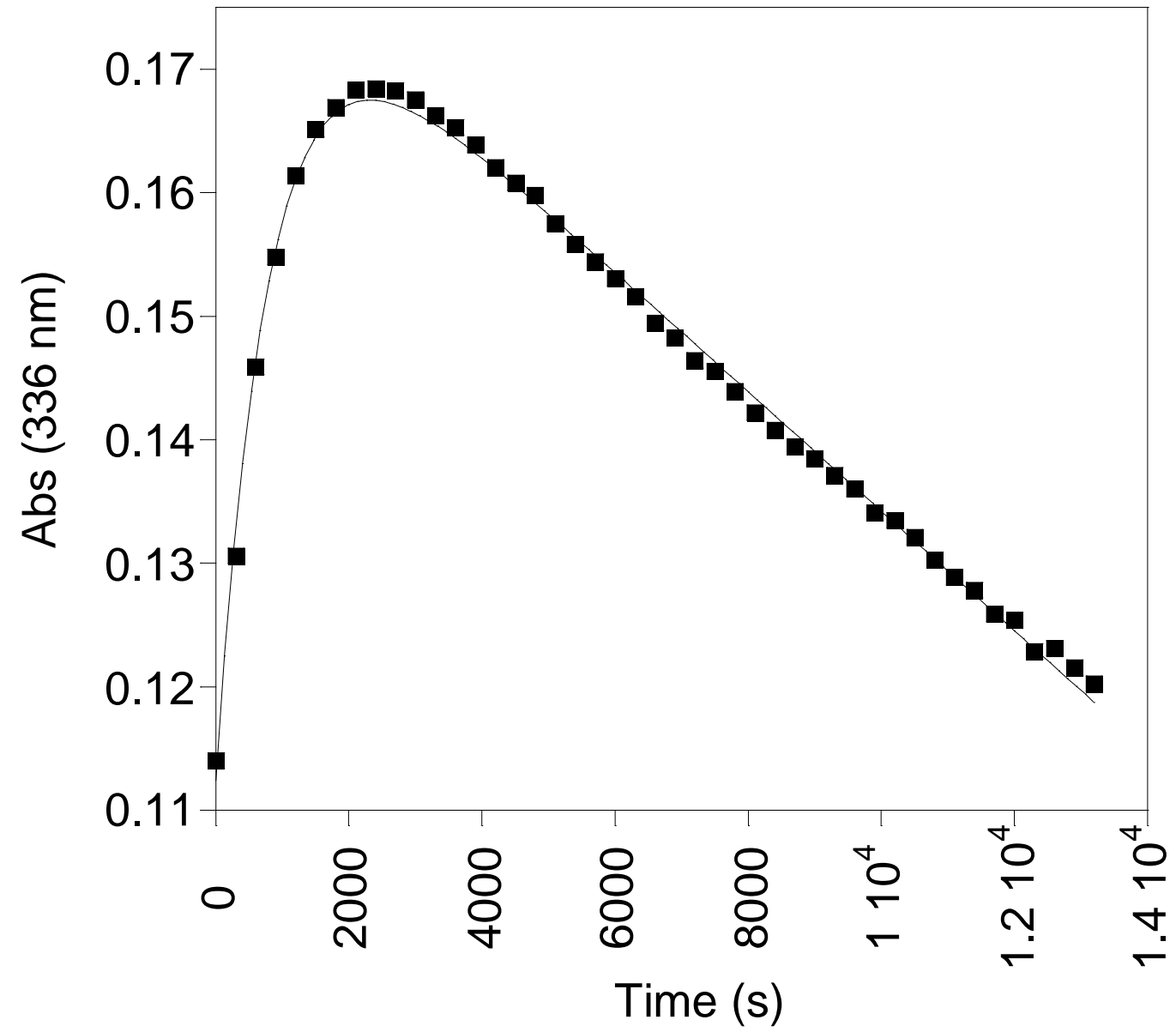

Figure S9 Kinetic trace for the reaction between cysteine $(50 \mathrm{mM})$ and $\mathrm{OSC}(=\mathrm{O}) \mathrm{NH}_{2}(0.61 \mathrm{mM}) /^{-} \mathrm{SC}(=\mathrm{O}) \mathrm{NH}_{2}(1.25 \mathrm{mM})$ in $0.10 \mathrm{M} \mathrm{NaOH}$. 


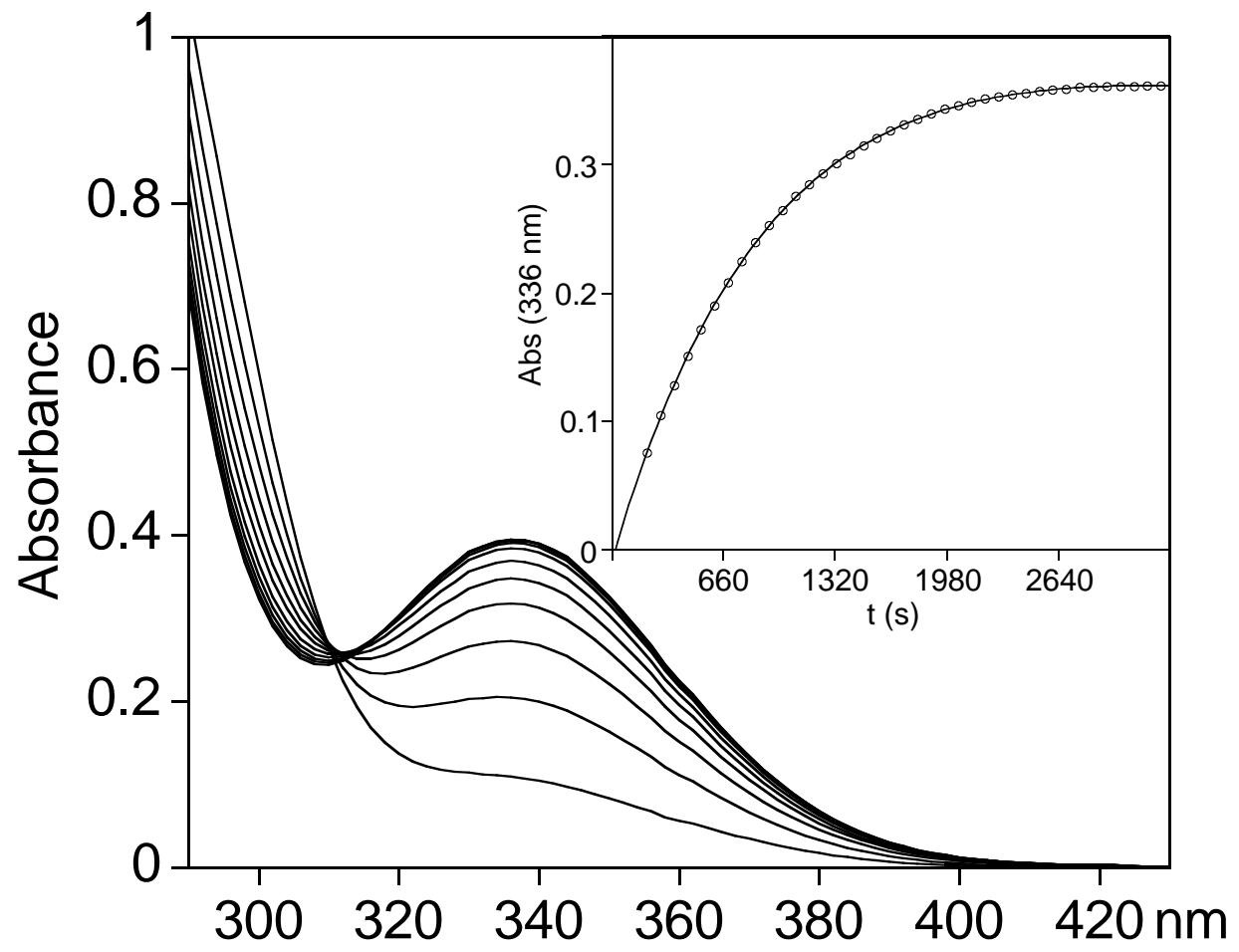

Figure S10. Time resolved spectra of the reaction of ${ }^{-} \mathrm{OSC}(=\mathrm{O}) \mathrm{NH}_{2}$ (generated by the hydrolysis of $\mathrm{OSCN}^{-}$) and cysteine at $\mathrm{pH}=13$. Spectra are $80 \mathrm{~s}$ apart. The pseudo first order rate constant was computed to be: $k_{\mathrm{obs}}=6.7 \times 10^{-4} \mathrm{~s}^{-1}$ using SVD analysis. Inset: Kinetic trace recorded at $\lambda=336 \mathrm{~nm}$ together with an exponential fit. Conditions: $\left[{ }^{-} \mathrm{OSC}(=\mathrm{O}) \mathrm{NH}_{2}\right]_{0}=10 \mathrm{mM}$, [cysteine $]_{0}=100 \mathrm{mM}, \mathrm{pH}=13, \mathrm{~T}=20$ ${ }^{\circ} \mathrm{C}$. 


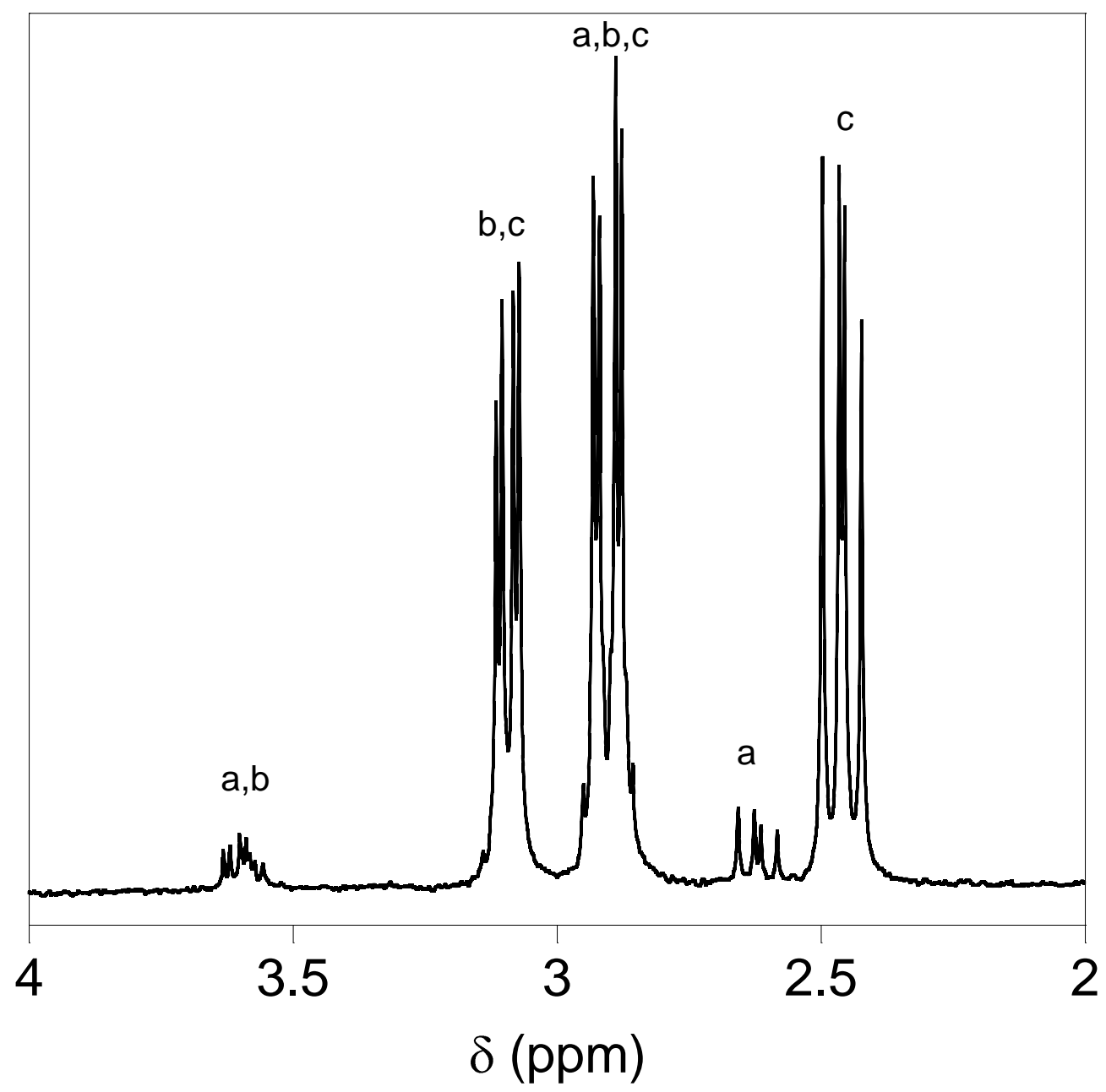

Figure S11. ${ }^{1} \mathrm{H}-\mathrm{NMR}$ spectrum for the reaction between $20 \mathrm{mM}$ cysteine and $2.5 \mathrm{mM}$ thiocarbamate-S-oxide $/ 5.0 \mathrm{mM}$ thiocarbamate (TCM) at $\mathrm{pH} 13.0$, with DSS as standard (after 50 minutes of reaction). Peak assignments: $\mathrm{H}_{2} \mathrm{NC}(=\mathrm{O}) \mathrm{SSCy}$ (doublet of doublets) = a, CySSCy (doublet of doublets) $=\mathrm{b}$, $\mathrm{CySH}$ (doublet of doublets $)=\mathrm{c}$. 


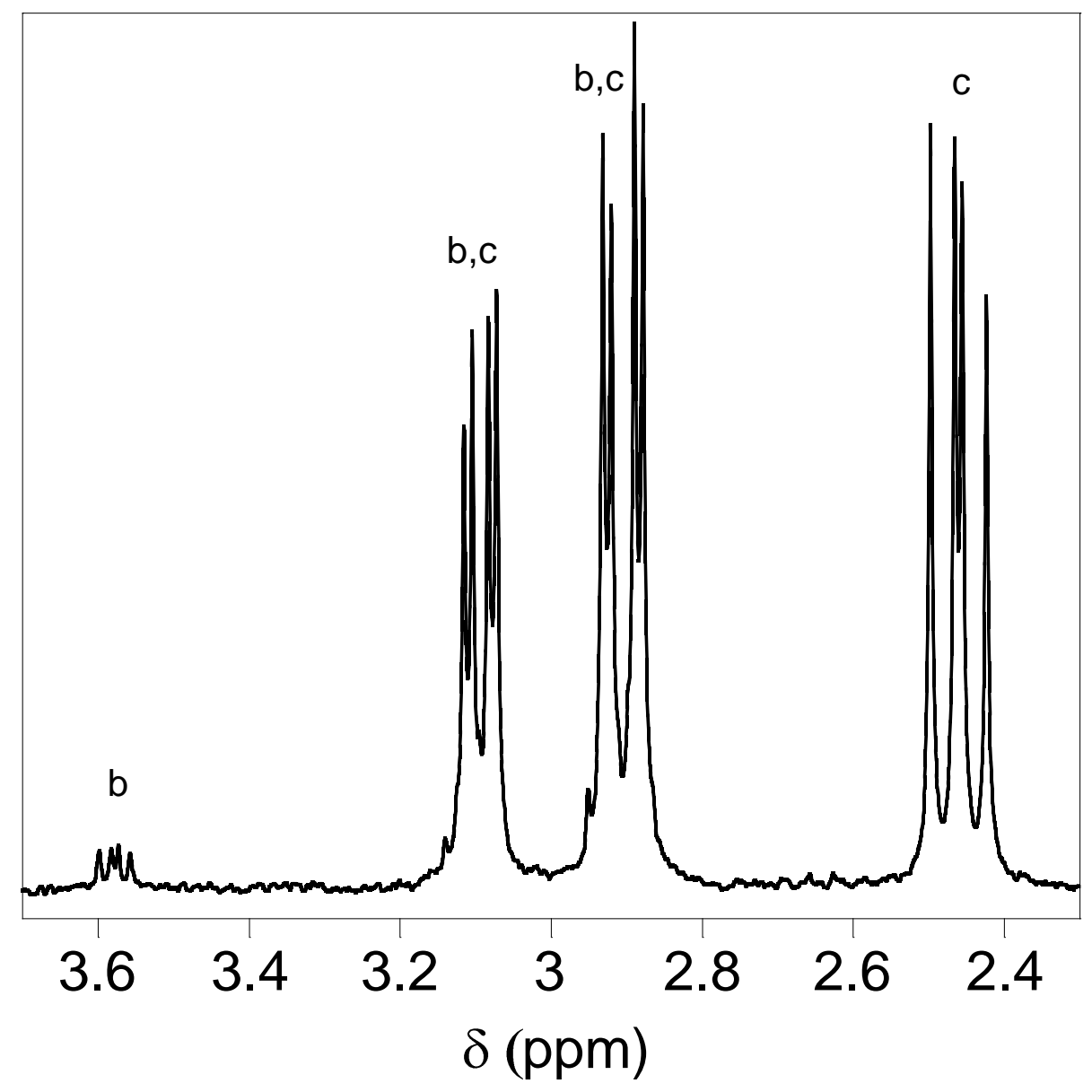

Figure S12. ${ }^{1} \mathrm{H}-\mathrm{NMR}$ spectrum for the reaction between $20 \mathrm{mM}$ cysteine and $2.5 \mathrm{mM}$ thiocarbamate-S-oxide $/ 5.0 \mathrm{mM}$ thiocarbamate (TCM) at $\mathrm{pH}$ 13.0, with DSS as standard (after 24 hours of reaction). Peak assignments: CySSCy (doublet of doublets) $=\mathrm{b}, \mathrm{CySH}$ (doublet of doublets $)=\mathrm{c}$. 